\title{
Kierkegaard and Shestov: "A Pilgrimage Among Human SOUl”. Reflections on Existential PhILOSOPHY ${ }^{1}$
}

\author{
Ivan Ivlampie \\ "Dunarea de Jos" University of Galati, Romania
}

\section{Resumen}

El presente estudio pretende enfatizar la única manera en la que el filósofo Lev Shestov entendió el pensamiento del filósofo danés, en su escrito, Kierkegaard y la filosofía existencial, publicado hacia el final de su vida. Aun así, Nikolái Berdyaev criticó a su cofrade, afirmando que ni Dostoievski ni Kierkegaard habían dicho lo que Shestov les había hecho decir. Esto es lo que da peso a la perspectiva del filósofo ruso, cuyo existencialismo explica temas y motivos semejantes a los de sus predecesores: la cuestión de la fe y la naturaleza irracional del hombre, el absurdo, el pecado, la libertad, el sufrimiento, la muerte, etcétera.

Palabras claves: Existencialismo, filosofía especulativa, conocimiento, ruptura, angustia.

\section{Abstract}

The present study aims to emphasise the unique way in which the philosopher Lev Shestov understood the Danish philosopher's thinking, in his writing, Kierkegaard and the Existential Philosophy, published towards the end of his life. Even so, Nikolái Berdyaev criticised his confrere, asserting that neither Dostoyevsky, nor Kierkegaard had ever said what Shestov made them say. This is what lays weight on the perspective of the Russian philosopher, whose existentialism accounts on themes and motives similar to those of his predecessors: the question of faith and the irrational nature of man, the absurd, sin, freedom, suffering, death, etc.

Key words: Existentialism, speculative philosophy, knowledge, breakdown, anxiety.

Well before his death, Kierkegaard was dismayed and infuriated by the idea that, after he died, Privatdozenten would present his philosophy as a complete system of ideas, arranged in sections, chapters, and paragraphs, and that amateurs of interesting philosophical structures would find it mentally enjoyable to follow the development of his thought. (Lev Shestov)

1 Recibido: 15 de julio de 2017; aceptado: 10 de agosto de 2017. 
It is only in 1928, ten years before his passing, that Lev Shestov (Lev Isaakovich Schwarzmann) becomes acquainted with Søren Kierkegaard's works and personality. Sensitive as the Eastern philosopher is to the singular voices of philosophy, to the lone voices crying in the wilderness, not only does this last discovery betray him, but especially the strength by which the Danish philosopher succeeds in entering the Europeans' philosophical conscience.

In 1935, Shestov finishes the volume Kierkegaard and the Existential Philosopby, in Russian. The translation into French is published the next year, while the original version is published one year after its author's death, in 1939. Just as Lev Shestov managed to place himself in the avant-garde of those who drew attention to the importance of Nietzsche's philosophy as early as 1900, he also succeeds in imposing Kierkegaard, with his study of the Danish philosopher, to a fairly wide francophone audience. It is in this context that we can understand the confession he makes in the beginning of the first chapter, entitled "Job and Hegel":

Kierkegaard bypassed Russia. Not once did I so much as hear his name in philosophical or literary circles. I am ashamed to admit it, but it would be a sin to conceal the fact that just a few years ago I knew nothing about Kierkegaard. Even in France he is all but unknown; it is only quite recently that a start has been made at translating him. His influence in Germany and the northern countries, however, has been immense. And that fact is of great importance; he has taken hold in the thinking, not only of the more distinguished German theologians, but also the philosophers, and even the professors of philosophy; it is enough to name Karl Barth and his school, on the one hand, and Jaspers and Heidegger on the other.

We can consider that Shestov's text on Kierkegaard is the fruit of five or six years of focus on reading and understanding the message of an unsettling work, hardly accessible to the European spirit used to reason within clear and unequivocal categories, in lucid reasoning which proves respect and categorical submission to the rules and principles of the logical laws. Is such a relatively short time enough for passing sentences in regard to such complex and inexhaustible a work as Kierkegaard's?

In Shestov's case, the answer can only be affirmative, based on a few considerations. The first pertains to the closeness of the two thinkers in what their similar existential experience is concerned. We can truly believe that, in reading the Danish philosopher, Shestov was reading himself. He also had an experience that is recorded as "the catastrophic event" in his biography. Even so, is 1895 the year of the climax of a crisis triggered by an 
unpleasant and exhausting effort, in the successful attempt of salvaging the family business, by an inner turmoil related to the moral dilemma induced by the love affair with the family's maid, Aniuta Listopadova ${ }^{2}$, who gives birth to an illegitimate son in 1892, and by the friendship with the young writer Varvara Grigoryevna Malakhieva-Mirovich, also an Orthodox. This passion ends with the essential event, which remains a secret, but which is betrayed by the moral quandary and the revolt against the imperative of ethics, which bursts out from this moment on in Shestov's soul. And Kierkegaard is not far from a similar experience, which, as shown further, he names "the thorn in the flesh".

Yet another consideration may rest on the fact that Kierkegaard appears on the horizon as a new opportunity for Shestov to apply his already trodden technique of pilgrimaging among souls. In his philosophical exercise, Shestov avidly tried to rouse those thinkers who did not resign themselves to sleeping under the restful breeze of syllogistic conclusions, of the abstract truths and principles which solace or send the spirit to sleep, but who sedulously and unremittingly experienced their tragic, existential and, at the same time, absurd truth, being not understood or accepted by their contemporaries. Shestov repeatedly asserts the idea that the tragic and the absurd of the existence remains, most often than not, anonymous, due to the majority's failure to express themselves artistically or philosophically. Against Hegelian philosophy, and, by and large, rationalist philosophy, the only way of philosophising would be the reanimation of the few survivors and unique confessors of metaphysical unrest who skilfully managed to sublimate and communicate, to a lesser or greater extent, their tragedy. This method, of "peering into another's soul" was intended to surprise the mysterious "you". On the other hand, in the Hegelian philosophy of history, seduced by simplified constructions, there is no possibility of communicating with remarkable people from the past, as it only provided "the development process", "the self-becoming of the concept". Even the great men, the greatest of them all, are mercilessly ground by the wheel of the historic process, and they hardly notice it, as if they were unanimated objects.

2 "A painful neuralgia, manifested through spasms and aches in the head and face, vouches for a complete physical and psychic fall, against the background of a depression worsened by the impossibility to reconcile the intransigence of moral imperatives (embodied by the "venerable" presence of the father) with the impulse of a "condemnable" passion for an Orthodox girl" (Ramona Fotiade, "Lev Şestov şi problema binelui" [Lev Shestov and the matter of good] in Lev Shestov, Filosofia tragediei [The Philosophy of Tragedy], Bucureşti: Univers Publishing House, 1997, p. 8). 
The philosophy of spirit rises above everything that is finite and evanescent. This is what Hegel claims - and in one of the chapters of his Lectures on the Philosopby of History, he imperturbably asserts that Socrates had to be poisoned and that it was not a bad thing: an old Greek died - is it so much ado about nothing worth?

Shestov is certain that the task of history and philosophy should be "a pilgrimage among human souls" and that the great philosophers "have always remained pilgrims among souls" 3 . The castaways of history - Job, Plotinus, Tertullian, Pascal, Luther, Nietzsche, Dostoyevsky, Tolstoy, etc. - are the greatest philosophers in Shestov's opinion. But, in 1928, Husserl draws his attention to yet another castaway: Kierkegaard.

What Shestov undertakes in his study can be regarded as an attempt at synthesising all his pilgrimages among the shouts of those who dared to escape from omnitude and from the soothing comfort of common consciousness, of those who still wander through the desert, under our staring eyes, in search of the tree of life, in search of faith. Shestov places Kierkegaard in the category of those who were courageous enough to look into what madness and death reveal to us; in the category of those who saw and heard what no one has ever seen or heard. This is the reason why these people have nothing in common with the others, not even at the level of language: they are the ones who detached themselves from the universal, who are named "the knights of faith" in Fear and Trembling ${ }^{4}$.

${ }^{3}$ Lev Shestov, Noaptea din grădina Ghetsimani [The Night in the Garden of Gethsemane], Iași: Polirom Publishing House, 1995, p.17.

4 "The knight of faith knows how beautiful and joyous it is to belong to the general. He knows how soothing it is to be an individual who adapts himself to the general, and, so to speak, publishes a second edition of himself: neat, pleasing to the eye, without errors, easy for all to read; he knows how good it is to understand yourself in the general, so that you yourself understand the general, and every other person who understands you, understands you in the general, and together with you rejoices in the peace which the general offers the soul. He knows how beautiful it is to be born the sort of man who has the general as his fatherland, for whom the general is an unfailing haven where he will always be received with open arms, where there must be refuge for him. But he knows that a lonely road, narrow and steep, winds above the general; and he knows the horror of being born lonely, of being born outside the general, of being condemned to go through life without meeting a single traveller along the way. He sees very clearly what his relationship is to other people. Humanly speaking, he has gone mad, and cannot make anyone understand him. And yet, "gone mad" is the very mildest expression. If they do not take him to be mad, people will declare him a hypocrite, and the higher he goes on his path, the more he will seem to all an utter hypocrite”. (Søren Kierkegaard, Frică şi cutremur [Fear and Trembling], Bucureşti: Humanitas Publishing House, 2002, pp. 145-146.) 
If Kierkegaard bypassed Russia, it does not mean that his spirit did not wander through this part of Europe. The same spirit can be encountered upon reading Dostoyevsky's works. In the preface to his book, Shestov emphasises the similarities between the two nineteenth-century writers who never met or had any knowledge about one another. We are confronted with a great enigma, partly explained by the syntagm "the spirit of the time" (zeitgeist). The enigma can be expanded even more by referring to one of Nietzsche's confessions in a letter to Franz Overbeck, dated on February $25^{\text {th }}, 1887$, two years before his nervous breakdown:

I didn't know the first thing about Dostoyevsky until a few weeks ago; I didn't even hear his name $-I$, the unlearned who does not read newspapers. I haphazardly laid my hand, in a bookstore, on the book L'esprit souterain in a recent translation into French (the same hazard operated in the case of Schopenhauer, in my $21^{\text {st }}$ year of life, and in that of Stendhal, in my $35^{\text {th }}$ ). The instinct of kinship (or what should I call it) asserted itself immediately, my joy was extraordinary: I must go back in time to the moment when I encountered [Le] Rouge et [le] Noir by Stendhal if I want to remember a similar pleasure. It's about two short stories ${ }^{5}$, the former being, in fact, truly music, an unknown, non-German music, and the latter, a brilliant psychological sketch, a form of self-mockery of the formula $\gamma v \tilde{\omega} \theta \iota$ $\sigma \varepsilon a v \tau \tau^{\prime} v^{6}$.) As an aside: these Greeks have a burdened conscience - falsification was their very craft, the entire European psychology suffers because of the Greek superficiality, and without the scarce Jewishness, etc. etc. ${ }^{7}$

Shestov probably did not encounter this text, or he would have fully valorised it. These lines reveal the intention which tied-in these three great writers of the nineteenth century, the war waged against the Greek conscience, but also the interpretation key used by Shestov in the understanding of the exhausting, indecisive battle that Kierkegaard fought with the Greek spirit. Be it as it may, in the very first paragraph of the Preface, one notes that Shestov associates the three great thinkers in the problem he wishes to present to the readership: the understanding of the original sin or of the difference between speculative truth and revealed truth, between theoretical (speculative) philosophy and existentialist philosophy.

${ }^{5}$ In the book, Notes from the Underground.

${ }^{6}$ Know thyself!

${ }^{7}$ Friedrich Nietzsche, Aforisme, scrisori [Aphorisms, Letters], Bucureşti: Humanitas Publishing House, 1992, p. 252. 
Two spiritual attitudes are noticeable in this respect. A dominant one, present in all European or Oriental cultural spaces, which regards sin or the horrors of life in the imperfection of the Creation, in a disorder of existence, dominated by the law of the inexorable disappearance of all the things that are born. This attitude represents the source of speculative philosophy and theoretical truth. The other attitude is underrepresented, avoided as much as possible by the great thinkers of all times, until the present day. Its 'obscure' source is a story named Genesis in the Book of All Books. The simple, well-known story of the six days of creative efforts, which end with the Creator's assessment "it was good", continues with the enigmatic event in the Garden of Eden, when the first humans, seduced by the serpent - "No! You will not die! God knows in fact that the day you eat it your eyes will be opened and you will be like gods, knowing good from evil." - tasted from the forbidden fruit and, faced with the good of the Creation, saw an overflow of evil. Knowledge brought about sin. This is the revealed truth! And it has scandalized and still scandalizes the most uplifted spirits of the humanity who placed their bets on reason and sensible knowledge.

Let's exemplify, alongside Shestov, with one of these spirits of same notable century, probably the last in the line of the greatest European philosophers: Hegel. Assimilating the entire European system of thinking, he steadily asserts that the serpent did not deceive the human being, and that we need to trace the origins of philosophy in the fruits of the tree of knowledge. With subtle irony, which otherwise characterises his opera omnia, though imperceptibly, Shestov admits that, historically speaking, Hegel is right. The fruits of the tree of knowledge have indeed turned into sources of philosophy, the sources of thinking for all times. All philosophers, and not only the pagan ones, but also the Jewish and Christian ones, who acknowledge the divine revelation in the Holy Writ, have always wanted to possess knowledge and have never agreed to give up the fruits of the forbidden tree. From such a stand, despiteful of everything that cannot be justified by reason in the Bible, Hegel considers, in his Lectures on the Philosophy of History, that we ought to give up a great deal of its narratives, and to interpret what is left of it so as not to offend our consciousness. God's omnipotence, present in miracles, should also be scornfully rejected, as it is a violation of the spirit, since "it requires the man to believe in things in which he can no longer believe once he has reached a certain position of culture (...). This faith, so required, is the faith in an accidental content, which is 
not true faith, because true faith does not have accidental contents" ${ }^{8}$. By deriding the biblical stories which only speak of the finite, the accidental, Hegel demands the reconciliation of religion with philosophy: religion must acquire its justification through philosophy, the only one capable of discovering "the necessary truth", as a revelation of "the Absolute Idea" in the diversity of religions.

Kierkegaard's formative years were based on Hegelian principles. But soon enough he feels the great deceit, the great temptation of his master: eritis scientes, you will be knowing by the biblical serpent, by abandonment of faith and wilful and unconditioned submission to the truths of reason. Confronted with this deceit, his only solution was to abandon the worldrenowned professor and embrace the "private thinker" Job as the only possible saviour. And Job will help him to find Abraham, the father of faith, for whom he seems willing to give up Socrates himself.

Kierkegaard found himself confronted with the impetuous EntwederOder [Either/ Or]. Either nothing is impossible to God, who promised to man power over all things in the world, or the entire reality is sensible and, faced with its truths, both created or Creator must submit. Either faith is above and beyond knowledge, or knowledge is more valuable than eternal redemption and, what is more, one can only know redemption through knowledge.

Along his entire writing, in this crucial point of Entweder-Oder, Shestov identifies Kierkegaard's fears, irresoluteness, weakness, indecision, his hesitations and toing and froing between the two antagonist poles of the spirit, reason and faith, between the grandiose manifestations of the extraordinary men who tried to illustrate with their deeds or ideas the true path to be followed by man in acquiring happiness and the greatest possible good. Faced with choosing a side, Kierkegaard was confronted with a thorn that entered deeply under his flesh: "As for me, a thorn was set in my flesh early in life. If it were not for that, I would from the beginning have lived an ordinary life" $"$.

${ }^{8}$ G.W. F. Hegel, Prelegeri de filosofie a religiei [Lectures on the Philosophy of History], Bucureşti: Humanitas Publishing House, 1995, p. 121.

9 Die Tagebücher I, 405. And on pages 276 and 277, he writes: "I am, in the real sense of the word, an unhappy man; I have, from my earliest years, been nailed down to a suffering which is driving me mad, a suffering which is bound up with some sort of abnormality in the relationship of my soul to my body... I spoke of this with my doctor and asked him whether he supposed that the abnormality might be cured, so that I could realize the general. He was doubtful of this. Then I asked him again, whether he did not think that 
What makes him choose Job and Abraham, and reject Hegel, Kant, Spinoza and, half-heartedly, Socrates? A life event which he refuses to mention and which he denies any curious person the right to investigate. In this context, Shestov remarks Kierkegaard's recourse to indirectness, by employing pseudonyms, but also the fact that we should not gnaw at this too much, as the "secret" that the Danish philosopher wants to conceal is transparent enough: "he was not able to become a husband". Breaking his engagement, not only did he separate from Regine Olsen for good, but he also broke up with society. While it may seem a trifle in the eyes of the contemporaries, it rises to Kierkegaard to the dimensions of a historical world event. It is not that exposed himself to public opprobrium, which falls into oblivion and brings forgiveness with the passing of time. It is rather about the condemnation of ethics, which never forgives or forgets, and in whose eyes, one can never be rehabilitated. Confronted with this nightmare, not only did Kierkegaard take his stand and turn appalled, but this predestined misfortune also brought him on the verge of despair. This is the starting point of existentialist philosophy: desperation, anxiety, and not wonderment, as Greek philosophy taught us. Ethics became the concrete and overwhelming hindrance to existentialist philosophy, whose main task was being outlined in outgrowing the moral imperatives.

Kierkegaard abandons Hegel as he could not find a place for his personal issues in the latter's philosophical system, a system which claims that reality is sensible and, more precisely, that it is as it should be and it should not be any different under any circumstances. However, abandoning Hegel means becoming a misologist, an antagonist of reason, a peril that Plato, Socrates' student, drew attention upon as early as the Antiquity. The Greeks' lesson is to love reason and necessity, whose entwinement makes up the universe. Reason teaches us that neither people nor gods can fight necessity. It is supreme, and any confrontation with it seems to be insanity. Kierkegaard does nothing but throwing himself in this battle, allowing the Absurd to embrace him. But the path to the Absurd is barred by Ethics, the ally

a man's mind could of its own will make some adjustment or set things right there. He had his doubts of this, too. He did not even advise me to try to exert all my strength of willwhich, he knew, could destroy everything together. From that moment, my choice was made. I accepted this unhappy abnormality (which would probably have led most people capable of understanding such horrible torment to commit suicide) as a thorn set in my flesh, as my limitation, my cross, as the enormous price for which the Heavenly Father has sold me my strength of mind, a strength which has no equal among my contemporaries." 
of Necessity. According to Shestov, not only does the Danish philosopher repudiate reason, but he is also forced to discontinue ethics, just as Job did. What are the means by which ethics can be discontinued? They are the cries and curses, which means waging a war with bare hands. Job waged this war. And what did he obtain? Repetition: he obtained everything twofold. Job defeats necessity and earns repetition! Excitedly, Kierkegaard exclaims: "I am waiting for the thunder - and for the repetition. And what does this repetition bring to me? It makes me good to be a husband" ${ }^{10}$. But what if Job falls in this unequal battle? These fears do not leave the Danish philosopher, who discontinues ethics to make the return to it possible, should Necessity win. This is why, as Shestov considers, he always introduces an ethical element in the understanding of religious.

"The greatest provocation to offense comes when man admits that what lies outside the realm of possibility for human reason is possible for God"11. Can Kierkegaard cope with this temptation? Shestov is certain that this is the field of the battle with Necessity and that Søren Kierkegaard was overwhelmed by this temptation. Only that there is weakness that is perceived in his efforts - he shows inconsequence. We have already seen that he keeps the ethics, which he only temporarily "discontinues". With the same irony, Shestov writes that if Kierkegaard wants to speak and be heard, he must gain the ethics over, he must dress up its garments. He was never abandoned by the anxiety induced by the authority of Necessity and by the judgement of his peers: He knew that his was a voice crying in the wilderness and that he was condemned to absolute loneliness and hopeless abandonment by circumstances he could not alter. Unable to pluck out the anxiety provoked by the eternal truths revealed by the Greeks, he discovered an instinctive fear of Nothingness in himself and the others, which led him to despair and to the titanic attempt at destroying both anxiety and nothingness. Although it was not him who discontinued ethics, but sooner ethics discontinued him. In its turn, ethics experiences the same paralysing anxiety in front of Nothingness. According to Shestov, Kierkegaard has the courage and the power to seek a new beginning in life, one that knows no fear and anxiety in front of Nothingness. Provisionally, this courage defines the greatness of existential philosophy: for a period of time, he gives up the

10 Søren Kierkegaard, Repetarea [Repetition], Timișoara: Amarcord Publishing House, 2000, p. 109.

${ }^{11}$ Søren Kierkegaard, Maladia mortală [The Sickness unto Deatb], Craiova: Omniscop Publishing House, 1998, p. 117. 
protection of ethics. But will he succeed or not in acquiring the final victory?

If Job awakened his courage and strength to ask for repetition, Abraham amazes him with his boldness and determination to discontinue ethics. "When I think about Abraham - writes Kierkegaard - it is as if I were utterly destroyed. At every moment, I see what an unheard-of paradox is presented by the content of Abraham's life; at every moment, something thrusts me back and, as hard as it tries, my thought is unable to penetrate the paradox. I do not move forward by so much as a hairs breadth. I exert my entire being in order to achieve my aim, but I immediately feel that I am totally paralyzed"12. In front of Abraham, Kierkegaard cannot accomplish the motion of faith, being aware that had he had faith, Regina would have stood by him. He lacked the ultimate courage of daring. A believer in the virtue of the absurd, Abraham did not lack the courage to raise the knife in order to slaughter his son, thus remaining a knight of faith for posterity, as opposed to the knight of resignation, designed by all those who do not dare, of those who decide to quit.

Abraham had faith. And having faith, admits Kierkegaard, means giving up reason in view of acquiring God. Reason led Socrates to resignation, to the awareness of his helplessness in front of Necessity. The lack of power that Kierkegaard feels, the same as Socrates's, is his lack of faith or, in other words, his exaggerate trust in reason. Confronted with the paralyzing $\mathrm{Ne}$ cessity, reason suggests us that we cannot get anywhere, and the ethics tells us that we must stop. Reason, with its aspirations to universal and necessary truths, and ethics, with its claim that resignation is the highest virtue, hide his own weakness from the human being, but also their own weakness. By hating reason and discontinuing ethics - paradoxical and absurd aspects we acquire faith, we acquire the strength and the power to ask, screaming and cursing, for repetition. And if we repeat what Shestov, walking in the footsteps of the Danish philosopher, constantly asserts, that the opposing notion of $\sin$ is not virtue, but faith, then the connection between weakness and sin becomes apparent.

Kierkegaard's personal experience as a sinner leads him to statements which do not correspond to the biblical text. In The Concept of Anxiety, commenting the following excerpt - "Innocence is ignorance. In innocence, man is limited, not spiritually, but mentally, in direct union with the natural state. Man's mind is still sleeping. This idea fully agrees with the Bible,

${ }^{12}$ Søren Kierkegaard, Frică şi cutremur [Fear and Trembling], ed. cit., p. 88. 
which does not recognize that man in the state of innocence has any knowledge of the difference between good and evil" ${ }^{13}$ - Shestov emphasises that nowhere in the Bible is written that the spirit of man, as moulded by the Creator's hands, would be asleep and that it might be awakened by acquiring the ability to know right from wrong. In the same work, Kierkegaard sees the original sin as a result of the anxiety of Nothingness: the state of innocence is, at the same time, anxiety.

Shestov, who believes that it is equally incorrect to discover the fear in the state of innocence, as it is to discover the slumber of spirit there, rejects this idea. Both slumber of spirit and fear - according to Bible - came after the fall. This is why the serpent is introduced into the narrative as an external, yet active principle of sorts. The serpent induced a phony fear to the first man: the anxiety of Nothingness, which turned overwhelming and invincible. And this anxiety sent the human spirit to sleep, paralysed the human will, and transformed his freedom in a state of senselessness. Kierkegaard expedites the serpent, considering that he cannot imagine any idea related to it. "No other book -writes B. Fundoianu, Shestov's discipleupset me as much as this one, in which Kierkegaard, set on establishing that sin is knowledge, let himself drawn, as hallucinated, to the open-mouth of the serpent" ${ }^{14}$.

Following the thread of the biblical narrative, Shestov is consistent with the aspects narrated: Man, in his state of innocence, which is also a state of freedom, did not trade the fruits in the tree of life for the fruits in the tree of knowledge; it is only the serpent that bewitched him and locked away his freedom. It is in the serpent's deed that we have to see the root of all evil: the fall represents knowledge and the ability to tell right from wrong. Knowing that the greatest martyrdom of man is his giving up reason, Kierkegaard assumed that the dread of the first man had been this possibility of losing his reason. Thus, the easy way in which the serpent succeeded in his temptation of making him taste from the fruits of the tree of knowledge in order to cast away the anxiety. Aside from the fact that Kierkegaard regards the present of the snake as unnecessary, since it cannot be sensibly explained (this is how Fundoianu's quotation should be interpreted), Shestov underlines the

13 Søren Kierkegaard, Conceptul de anxietate [The Concept of Anxiety], Timişoara: Amarcord Publishing, House, 1998, p. 77.

${ }^{14}$ B. Fundoianu, "Şestov, Kierkegaard şi şarpele" [Shestov, Kierkegaard and the Serpent] in Conştiința nefericită [The Wretched Conscience], Bucareşti: Humanitas Publishing House, 1993, p. 250. 
fact that the greatest discovery of existential philosophy in the mystery of the fall from grace is the identification of fear with "the dread of Nothingness".

Starting from this discovery, Shestov considers that both: God and the tempting serpent had the Nothingness at their disposal. God created both universe and man out of nothing, and the latter did not go beyond the limits of his condition and, without God, would have never acquired a meaning of his existence. Through the dread inspired to man after the fall, nothingness turned into a huge, destructive force: it became Nothingness.

Nothingness ceased to be nothingness, ceased to be non-existent. It became existent and, together with its lack of being, established itself and took root in all that exists-although there was absolutely no need for it to be. Nothingness has turned out to be a mysterious Proteus. Before our eyes it has transformed itself, first into Necessity, then into the Ethical, then into Eternity. And it has fastened its chains, not only upon man, but also upon the Creator Himself. It cannot be fought by ordinary means. There is no way to get at it, no way to overcome it - it hides beneath its lack of being whenever it senses the approach of danger. And-from our point of view-God finds it even more difficult to contend with than man does. God abhors coercion. There is nothing that Nothingness abhors. It is maintained by coercion alone, and accomplishes nothing but coercion in its unforeseen and totally superfluous existence. $^{15}$

Nothingness appropriated the predicate of existence as if it had always belonged to it. Confronted with this illegitimate act, not only did Reason keep silent, but it also consolidated the power of Nothingness, transforming it into Fate, Necessity, Ethics, and Eternity.

The moment man chose the tree of knowledge, that is, the freedom of choosing between right and wrong, meant, according to Shestov, the loss of his freedom. Human freedom is not about choosing between right and wrong, but about the world's deliverance from evil. Authentic freedom destroys evil, turning it into nothingness, but not in that Nothingness which destroys and ruins whatever stands before it and which considers itself at the same level with Existence, and which appropriated the predicate of being for its own use, but in that nothingness devoid of will and power from which God created the world. Man will only acquire freedom when he de-

15 Лев Шестов (Lev Shestov), Киргегард и экзистенциальная философия [Kierkegaard and Existential Philosophy], Издательство Гнозис, Прогресс, 1992. See chapter XVIII "Despair and Nothingness". 
stroys Nothingness for good, only when, returning to the tree of life, knowledge loses its power over him. Kierkegaard believed that ignorance was the slumber of spirit; Shestov argues the exact opposite: this belief is an illusion, the death of the spirit; knowledge enslaves the human will, submitting it to the eternal truths. This idea is not a far cry from what Nietzsche wrote in The Birth of Tragedy.

As soon as that daily reality comes back again into consciousness, one feels it as something disgusting. The fruit of this condition is an ascetic condition, in which one denies the power of the will. In this sense, the Dionysian man has similarities to Hamlet. Both have had a real glimpse into the essence of things. They have understood, and it now disgusts them to act, for their actions can change nothing in the eternal nature of things. They perceive as ridiculous or humiliating the fact that it is expected of them that they should set right a world turned upside down. The knowledge kills action... ${ }^{16}$

We can infer, as Shestov does, that the state of ignorance, of emancipation from knowledge is the beginning of man's liberation, of freedom's awakening from its senselessness. The senselessness of freedom is the condition of possibility for knowledge. In ignorance, the spirit is awake, whereas knowledge brings man closer to slumber; the fall was the beginning of knowledge; the sin and knowledge are, therefore, synonymous. The knowledgeable man, who strives to make sure that what exists ("daily reality", according to Nietzsche), "must necessarily exist this way and not any other" (Kant) or that "what is real is also sensible" (Hegel), discovers a destiny which does not exist. For the ignorant man, as long as he stays ignorant, the destiny does not exist.

These assertions were not Kierkegaard's, but Shestov's inferences from his indecisive, contradictory, and sometimes so bold statements, which cannot be attributed to a knight of resignation. We sometimes encounter, in the Danish philosopher's case, the certainty that the ability to know right from wrong is a spiritual evolution, and that man was unfulfilled before the fall, not knowing to tell right from wrong. But he also asserts: "the possibility of freedom is not that of being able to choose right or wrong. Neither the Holy Writ, nor thinking support such recklessness. The possibility [of freedom] is that of being able" 17 .

${ }^{16}$ Friedrich Nietzsche, "Naşterea tragediei" [The Birth of Tragedy], in De la Apollo la Faust, Bucureşti: Meridiane Publishing House, 1978, p. 209.

${ }^{17}$ Søren Kierkegaard, Conceptul de anxietate [The Concept of Anxiety], ed. cit. p. 86 
This courageous understanding of freedom agrees with Kierkegaard's repeated statements to which Shestov constantly refers, which claim that "everything is possible to God"18. This statement, also present in the Holy Writ, represents the fundamental thesis of existential philosophy, one unacceptable for speculative philosophy, and also for the historical, institutionalized Christianity. How can we accept the paradox that whatever is impossible within human reason is possible to God? To believe that "everything is possible to God" is a decisive strike against reason, which does not tolerate any other authority than itself, and which, by virtue of this, has constantly subverted the power of faith. The reason sees, clearly and distinctly, where everything that is possible ends, and does not accept faith, which searches for truth in a God that is alive, unconfined and free. With Shestov, the antithesis between rational and irrational, between impossible and possible, between the obvious and the revealed truth takes shape as a war between Athens and Jerusalem, or as an alternative between the tree of knowledge and the tree of life. The exegesis of Kierkegaard's works already announces the ideas from his last book, a genuine synthesis of his entire essayistic activity, which is entitled Athens and Jerusalem.

18 "But for God all things are possible. This constitutes the struggle of faith: a mad struggle for possibility. For only possibility reveals the way to salvation. In the last analysis one thing remains: for God, all things are possible. And only then is the way to faith made open. Man believes only when he cannot find any other possibility. God signifies that everything is possible, and that everything is possible signifies God. And only that man whose being has been so shaken that he becomes spirit and grasps that everything is possible, only he has drawn near to God”. (Søren Kierkegaard, Maladia mortal [Sickness onto Death], ed. cit., pp. 37-39.)

"I have repeated these words by Kierkegaard so many times because they express in a remarkably concrete and vivid form the basic concept of existential philosophy: for God, everything is possible. That is also what was meant by his violent attacks on the church. The church and Christianity, by living in peace and harmony with reason, abolish Christ, abolish God. One cannot «live» with reason." (Lev Shestov, XX, "God and Coercive Truth").

"Kierkegaard, in venturing to declare that for God everything is possible, departed from the broad road along which thinking humanity, even Christianly thinking humanity, is moving. For him, «triumphant», «victorious», recognized Christianity was a Christianity that had abolished Christ, i.e., God. But on paths unknown to anyone, in wildernesses where no one had even made paths, his ears caught the silent voices of men unknown and unnecessary to anyone: men with the «courage» to look at what madness and death reveal to us. They have seen and heard things that no one has ever heard and seen before. That is why they have nothing, not even language, in common with all the others; these are men who have «withdrawn from the general»" (Lev Shestov, XIX, "Freedom"). 
In his conclusions, about the value of Kierkegaard's confessions, Shestov is certain that they were forced out of him through torture - the horrors and burden of his entire existence. This torture insinuated the fear in his soul, as in the souls of us all: "We are afraid of everything, even of God, and we don't dare to believe in Him as long as we haven't been previously persuaded that $\mathrm{He}$ is not a threat. And no sensible argument can dispel this fear; on the contrary, the sensible arguments feed it" ${ }^{19}$.

All the writings of the Danish thinker discuss the desperate struggle of man with the original sin and its consequences. Reason and ethics brought Kierkegaard to qualm and despair. THIs state, manifested as the dread of nothingness, appeared in the world as a consequence of sin, making the human being a slave. Kierkegaard's vivid and painful experience gave him the opportunity to authentically identify the sin and the helplessness of the will, to glorify the Absurd, which leads the path to faith. He could not accomplish the "movement of faith", his will was paralysed, his freedom fell into senselessness, but he loathed and cursed his helplessness. Isn't that Shestov wonders - isn't that the faith itself, the authentic, veritable faith?

\section{Bibliography}

Kierkegaard, Søren, Conceptul de anxietate [The Concept of Anxiety], Timişoara: Amarcord Publishing House, 1998.

- Maladia mortal [Sickness onto Death], Craiova: Omniscop Publishing House, 1998.

- Frică şi cutremur [Fear and Trembling], Bucureşti: Humanitas Publishing House, 2002.

- Repetarea [Repetition], Timişoara: Amarcord Publishing House, 2000.

- "Sau-Sau" [Either/or] in Opere [Works], vol. II, București: Humanitas Publishing House, 2006.

- Die Tagebücher. Ausgewählt und übers. von Th.Haecker. Bd. I - II. Innsbruck: Brenner Verlag, 1923.

Dostoyevsky, F. M., Jurnal de scriitor [A Writer's Diary], vol. 1-3, Iaşi: Polirom Publishing House, 1998-2000.

Dostoyevsky, F.M., Însemnări din subterană [Notes from the Underground], Iaşi: Timpul Publishing House, 1999.

${ }^{19}$ Lev Shestov, chapter XXII, "Conclusions". 
Fundoianu, B. "Şestov, Kierkegaard şi şarpele" [Shestov, Kierkegaard and the Serpent] in Conştiința nefericită [The Wretched Conscience], Bucureşti: Humanitas Publishing House, 1993.

Hegel, G.W. F., Prelegeri de filozofie a religiei [Lectures on the Philosophy of Religion], Bucureşti: Humanitas Publishing House, 1995.

Nietzsche, Friedrich, Aforisme, scrisori [Aphorisms, Letters], Bucureşti: Humanitas Publishing House, 1992.

- "Naşterea tragediei" [The Birth of Tragedy], in De la Apollo la Faust [From Apollo to Faust], Bucureşti: Meridiane Publishing House, 1978.

Shestov, Lev, Noaptea din grădina Ghetsimani [The Night in the Garden of Getbsemane], Iasi: Polirom Publishing House, 1995.

- Filosofia tragediei [The Philosophy of Tragedy], Bucureşti: Univers Publishing House, 1997.

- Începuturi şi sfârşituri [Beginnings and Ends], Iaşi: Institutul European Publishing House, 1993.

Шестов, Лев, Афины и Иерусалим [Athens and Jerusalem], Издательство „Азбука”, Санкт-Петербург, 2001.

- Киргегард и экзистенциальная философия [Kierkegaard and Existential Philosophy], Издательство Гнозис, Прогресс, 1992. 